\title{
NILAI MORAL DALAM NOVEL MERRY RIANA MIMPI SEJUTA DOLAR KARYA ALBERTHIENE ENDAH DAN IMPLIKASINYA TERHADAP PEMBELAJARAN BAHASA INDONESIA DI SMA
}

\author{
Diah Amelia Sari \\ Universitas Pancasakti Tegal \\ Pendidikan Bahasa dan Sastra Indonesia, FKIP, Tegal \\ diahameliasari4@gmail.com
}

\begin{abstract}
Abstrak
Tujuan penelitian ini adalah untuk mendeskripsikan nilai moral yang terdapat dalam novel Merry Riana Mimpi Sejuta Dolar Karya Alberthiene Endah dan untuk mendeskripsikan implikasi terhadap pembelajaran bahasa Indonesia di SMA. Nilai moral ialah sesuatu atau suatu nilai yang berkaitan dengan pribadi seseorang masing-masing, seseorang yang membuat tingkah lakunya sendiri baik atau buruknya. Ada tiga jenis wujud nilai moral yaitu (1) hubungan manusia dengan diri sendiri, (2) hubungan manusia dengan manusia lain dalam lingkup sosial, dan (3) hubungan manusia dengan Tuhanya.Metode yang digunakan adalah metode deskriptif kualitatif. Sumber data yang digunakan dalam penelitian ini adalah novel Merry Riana Mimpi Sejuta Dolar Karya Alberthiene Endah. Wujud data yang digunakan berupa kata, frasa, dan kalimat yang menunjukan nilai moral dalam novel Merry Riana Mimpi Sejuta Dolar Karya Alberthiene Endah. Pengumpulan data menggunakan teknik baca dan teknik catat. Teknik analisis data penelitian ini menggunakan teknik analisis deskriptif kualitatif. Pada tahap penyajian digunakan metode informal. Hasil penelitian ini menunjukan bahwa nilai moral yang terdapat dalam novel Merry Riana Mimpi Sejuta Dolar Karya Alberthiene Endah menghasilkan data kutipan sebanyak 40 data. Hasil penelitian ini dapat dijadikan sebagai alternafif materi ajar di SMA dikarenakan isi yang terkandung di dalamnya sangat positif. Sifat-sifat positif itulah yang pantas dijadikan contoh bagi peserta didik.
\end{abstract}

Kata kunci: Nilai Moral, novel, implikasi pembelajaran.

\section{PENDAHULUAN}

Sastra dengan prosesnya adalah perceminan keadaan seseorang. Karya sastra biasanya menggambarkan berbagai permasalahan kehidupan. Kehidupan adalah kenyataan sosial yang merupakan sebuah cermin masyarakat yang digambarkan melalui tokoh-tokohnya.
Hasil karya sastra berupa novel, puisi, cerpen ataupun drama telah dikenalkan pada setiap peserta didik sejak di bangku sekolah. Tentunya terdapat di mata pelajaran Bahasa Indonesia pembelajaran tersebut dengan tujuan untuk memberikan pengetahuan siswa mengenai sastra terdapat untuk kemampuan mengapresiasi serta meneliti hal yang ada disuatu karya. 
Novel adalah media bermanfaat untuk pembelajaran di SMA sesuai dengan kurikulum yang sekarang berlaku. Novel Merry Riana Mimpi Sejuta Dolar yaitu novel yang banyak diminati oleh para remaja, dalam novel ini memuat cerita motivasi dan tingkah laku Merry Riana yang pentang menyerah, pekerja keras, gigih, disiplin, religius dan percaya diri meraih cita-citanya berhasil sukses. Merry selaku pemeran dalam novel ini pantas sebagai sesuatu yang ditiru serta dicontoh untuk pembaca yang kebingungan melalui keadaan terlalu banyak tantangan .

Moral yang disampaikan untuk pembaca dari karya fiksi sungguh bermanfaat. Demikan moral yang ada dalam novel Merry Riana Mimpi Sejuta Dolar berguna untuk pembaca. Moral yang ada dalam novel ini bersangkutan hubungan manusia dengan diri sendiri, hubungan manusia dengan manusia dalam lingkungan sosial, hubungan manusia dengan Tuhannya.

Kekerasan terhadap etnis Tionghoa di Indonesia masih terjadi di berbagai kota, khususnya di ibu kota Jakarta pada 13-16 Mei 1998. Dalam kerusuhan ini terjadi banyak perusakan, sentimen terhadap etnis Tionghoa. Banyak isu kebencian yang tersebar luas pada pengusaha Tionghoa, sehingga kerusuhan ini disebut juga dengan kerusuhan anti Tionghoa. Hal ini dapat dibuktikan dengan berbagai aksi perusakan fasilitas umum, rumah warga, serta pada kawasan-kawasan perniagaan yang umumnya dimiliki oleh pengusaha Tionghoa.

Tokoh perempuan yang dihadirkan oleh Alberthiene Endah di novel Merry Riana Mimpi Sejuta Dolar ialah tokoh yang mandiri, pekerja keras, dan pantang menyerah, yakin untuk meraih cita-citanya berhasil untuk sukses. Merry menjadi wanita tahan banting yang bisa menyelesaikan studinya di Singapura walaupun banyak rintangan yang dihadapinya menjadi seorang anak muda dengan penghasilan lebih dari satu juta dolar. Novel Merry Riana Mimpi Sejuta Dolar Karya Alberthiene Endah contoh untuk orang lain bekerja dengan giat untuk mencapai keberhasilan. Novel ini adalah paling laris terjual ditahun 2012 serta Merry Riana saat ini sosok perempuan pendorong untuk memotivasi orang lain sehingga berhasil untuk sukses menginspirasi orang lain. Usaha tingkah laku tokoh Merry untuk menginspirasi orang lain, sebenarnya novel ini memuat banyak tingkah laku yang baik serta bisa ditiru banyak orang.

peneliti akan mengambil permasalahan tersebut dalam judul "Nilai Moral dalam Novel Merry Riana Mimpi Sejuta Dolar Karya Alberthiene Endah dan Implikasinya Terhadap Pembelajaran Bahasa Indonesia di SMA". Peneliti 
menemukan banyak hal yang menarik dalam ceritanya, begitu banyak ditemukan nilai moral yang ada manfaatnya. Penulis telah berhasil menceritakan kehidupankehidupan yang banyak mengandung nilai moral dituangkan dalam suatu karya sastra. Peneliti ini memiliki rumusan masalah yaitu: 1) Bagaimana nilai moral dalam novel Merry Riana Mimpi Sejuta Dolar Karya Alberthiene Endah? 2) Bagaimana implikasi pembelajaran aspek moral novel Merry Riana Mimpi Sejuta Dolar Karya Alberthiene Endah terhadap pembelajaran Bahasa Indonesia di SMA? Peneliti mempunyai pembatas masalah dalam penelitian ini yaitu: 1) Pembatasan masalah ialah fokus dalam penelitian supaya tercakup tahapan yang disediakan. Batasan masalah memiliki tujuan agar dimengerti. Pembatasan masalah dalam penelitian ini ialah Nilai Moral dalam Novel Merry Riana Mimpi Sejuta Dolar Karya Alberthiene Endah dan Implikasinya Terhadap Pembelajaran Bahasa Indonesia di SMA. Mengenai tujuan penelitian ini yaitu: 1) Mendeskripsikan nilai moral dalam novel Merry Riana Mimpi Sejuta Dolar Karya Alberthiene Endah. 2) Mendeskripsikan implikasi pembelajaran nilai moral novel Merry Riana Mimpi Sejuta Dolar di SMA. Menurut latar belakang di atas mempunyai manfaat penelitian dalam Penelitian ini supaya mampu memperoleh tujuan yang optimal serta bermanfaat secara umum. Penelitian ini diharapkan mampu memberikan manfaat. Ada dua manfaat yang diangkat dari penelitian ini baik manfaat teoritis ataupun manfaat praktis. a. Manfaat teoretis: (1) Memberikan pengetahuan tentang nilai moral dalam novel Merry Riana Mimpi Sejuta Dolar Karya Alberthiene Endah. b. manfaat praktis: (1) penelitian ini supaya mampu menambah pengetahuan tentang nilai-nilai moral sebagai aktivitas pelajaran atau diluar pelajaran. (2) penelitian ini supaya mampu menambah pengalaman siswa menerapkan nilai moral dalam kehidupan sehari-hari.

\section{KAJIAN TEORI}

\subsection{Novel}

Mulyono (2020) mengemukakan novel yaitu jenis dari sebuah karya. Novel dihasilkan dari realita peristiwa kehidupan dikemas sedemikian rupa dan menciptakan hal-hal baru melalui cerita-cerita yang ditampilkan. Novel juga dapat memberikan pengalaman tidak langsung kepada para pembacanya. Melalui pengalaman tersebut diharapkan dapat merubah cara berperilaku agar menjadi lebih baik.

Novel adalah cerita fiksi menggambarkan dari peristiwa atau pengalaman pengarang. Pengalaman orang lain yang didengar atau hasil imajinasi pengarang. Novel pada umumnya berisi 
gagasan pengarang yang ingin disampaikan kepada pembacanya. Hal tersebut dapat berbentuk nilai-nilai kehidupan, budaya atau sosial sehingga pembaca dapat memahami hikmah dan amanat yang terkandung dalam novel.

\section{Nilai Moral}

Nilai moral yaitu perbuatan baik atau buruk dalam bertingkah laku. Nilai moral mengenai sesuatu hal yang berhubungan dengan perbuatan manusia. Seseorang yang memiliki moral akan terlihat pada tingkah lakunya baik ataupun buruknya.

\section{Jenis dan Wujud Moral}

Dalam sebuah karya terdapat amanat atau pesan yang berbeda-beda isinya. Ajaran moral meliputi persoalan kehidupan yang ada dalam novel. Menurut Nurgiantoro (2013:411-412) jenis wujud moral dikelompokan menjadi tiga sebagai berikut.

1) Hubungan manusia dengan diri sendiri

Wujud moral memiliki hubungan sebagai individu yang dapat menunjukan diri individu tersebut. Individu tersebut mempunyai sikap dan tingkah laku yang melekat dalam pribadinya diri sendiri.

\section{2) Hubungan manusia dengan} manusia dalam lingkup sosial
Hubungan Manusia dengan manusia hakikatnya membangun hubungan bermasyarakat karena membutuhkan bantuan dari orang lain. Manusia ialah yang berhubungan secara timbal balik dengan manusia lain, manusia tidak bisa hidup sendiri tanpa saling membantu orang lain. Persoalan tersebut berhubungan dengan sopan, peduli, tolong-menolong, saling berbagi dan menepatin janji.

\section{3) Hubungan manusia dengan Tuhan}

Seorang manusia tidak dapat dipisahkan dari penciptanya. Semua kebutuhan dan keperluan manusia akan selalu tertuju pada penciptanya. Hubungan manusia dengan Tuhanya guna bersyukur atas nikmat yang diberikan dan menjauhi larangannya.

\section{Implikasi Pembelajaran Bahasa} Indonesia di SMA

Kompetensi Dasar dalam Pemebelajaran Bahasa Indonesia di SMA kelas XII adalah KD 3.9 menganalisis isi dan kebahasaan novel, siswa diarahkan untuk menentukan isi novel berdasarkan unsur intrisik dan ekstrinsik. Novel yang disajikan dapat menambah pengetahuan siswa, karena dalam novel menceritakan tentang kehidupan. Tujuannya pada 
pembelajaran novel sendiri yaitu agar peserta didik memliki pengetahuan tentang novel, dan sikap positif terhadap novel.

Penelitian fokus nilai moral terdapat di novel sebagai pembelajaran karakter siswa di SMA. Dalam mengapresikan novel kita bisa mengajarkan nilai kejujuran dalam melakukan sesuatu, kebaikan sesama manusia, persahabatan antar teman, kekeluargaan yang bahagia, keikhlasan dalam mendapatkan cobaan, ketulusan dalam melakukan sesuatu dan lain sebagiannnya yang bisa kita contohkan terhadap siswa melalui sastra. Dan siswa mampu menerapkan pendidikan karakter malalui novel dalam kehidupan seharihari, dapat mengapresikan sastra dengan bagus dan mampu merangsang kepekaan siswa terhadap pemahaman suatu karya sastra.

\section{METODE PENELITIAN}

\subsection{Metode Penelitian}

\section{Pendekatan Penelitian}

Penelitian dinovel Merry Riana Mimpi Sejuta Dolar Karya Alberthiene Endah yaitu dengan memakai jenis penelitian kualitatif deskriptif. Metode deskriptif karena data berisi kutipan kalimat bisa paha, peristiwa yang sedang terjadi dalam penelitian(Meleong, 2016:11). Data yang digunakan dalam peneliti berisi kalimat yang terdapat dalam novel tersebut.

Metode digunakan peneliti adalah kualitatif karena metode tersebut tepat untuk mencapai tujuan penelitan secara maksimal pada penelitian ini lebih mengutamakan pengumpulan data berbentuk verbal yang sedalam-dalamnya. Dikatakan kualitatif tidak memerlukan perhitungan angka hanya mendeskripsian yang semaksimal mungkin. Hariwijaya (2015: 85-85) menuliskan bahwa penelitian kualitatif tidak teralalu fokus besar kecilnya populasi. Misalkan data yang sudah ada bisa dipahami maka tidak usah mencari sampling yang lainnya.

\section{Jenis Penelitian}

Penelitian ini menggunakan jenis penelitian metode deskriptif. Metode deskriptif mempunyai tujuan memberikan paparan, memberikan gambaran, dan memberikan penjelasan secara nyata dan rinci dalam keadaan dan peristiwa yang akan dikaji.

\subsection{Data dan Sumber Data}

\section{Data}

Data yang digunakan dalam peneliti berisi kalimat yang terdapat dalam novel tersebut. Metode digunakan peneliti adalah kualitatif 
karena metode tersebut tepat untuk mencapai tujuan penelitan secara maksimal pada penelitian ini lebih mengutamakan pengumpulan data berbentuk verbal yang sedalamdalamnya. Dikatakan kualitatif tidak memerlukan perhitungan angka hanya mendeskripsian yang semaksimal mungkin.

\section{Sumber Data}

Dalam memperoleh data peneliti memerlukan sumber data. Sumber data yaitu bahan dari penelitian untuk memperoleh data dari hasil penelitian. Sumber data yang digunakan dari data utama yaitu novel Merry Riana Mimpi Sejuta Dolar Karya Alberthiene Endah, yang diterbitkan oleh PT. Gramedia Pustaka Utama tahun 2012 di Jakarta.

\subsection{Teknik Pengumpulan Data}

Peneliti memakai teknik baca dan teknik catat dalam pengumpulan datanya. Langkah pertama yaitu melakukan membaca dengan cermat dan teliti terhadap novel Merry Riana Mimpi Sejuta Dolar Karya Alberthiene Endah. Setelah ditemukan yang data dibutuhkan selanjutnya, peneliti melakukan pencatatan. Setelah dicatat kemudian data dianalisis. Disajikan hasil analisis dalam bentuk deskriptif.

\subsection{Teknik Analisis Data}

Peneliti menggunakan teknik kualitatif. Data peneliti dapatkan diklarifikasikan sesuai posisi yang sudah ada. Teknik ini memberikan gambaran dan menginterprestasikan arti data sedalam mungkin sesuai dengan tujuan penelitian yaitu mendeskripsikan nilai moral pada novel Merry Riana Mimpi Sejuta Dolar Karya Albrthiene Endah. Teori yang diterapkan penelitian ini merupakan teori dari Keraf dengan menganalisis hubungan secara logis dan sistematis.

\section{HASIL PEMBAHASAN DAN PENELITIAN}

\section{A. Hasil dan Pembahasan}

Dalam novel Merry Riana Mimpi Sejuta Dolar Karya Alberthiene Endah ada 363 halaman. Novel ini menceritakan tentang tokoh perempuan yang mandiri, pekerja keras, dan pantang menyerah, yakin untuk meraih cita-citanya berhasil untuk sukses. Merry menjadi wanita tahan banting yang bisa menyelesaikan studinya di Singapura walaupun banyak rintangan yang dihadapinya menjadi seorang anak muda dengan penghasilan lebih dari satu juta dolar.

\section{a. Hubungan Manusia dengan Diri Sendiri}

Hubungan manusia dengan diri sendiri menyangkut sikap batin seseorang. Batin seseorang erat kaitannya dengan hati nurani, yang 
merupakan penghayatan baik atau buruk mengenai perilaku manusia yang terkait dengan situasi dan kondisi yang nyata. Hati nurani manusia akan merefleksikan dirinya sendiri terutama mengenal orang lain. Nilai moral berupa hubungan manusia dengan diri sendiri meliputi teguh pada pendirian, optimis, dan penyesalan.

\section{Teguh pada Pendirian}

Kehidupan seseorang pasti memiliki sebuah proses. Teguh pendirian yaitu seseorang yang mempunyai keyakinan yang tidak bisa berubah-ubah. Seseorang yang mempunyai prinsip teguh pendirian sangat yakin ketika akan melakukan sesuatu tidak bisa dirubah dan tidak tergoyahkan ketika mendapatkan sebuah rintangan. Ditemukan ada 2 data dalam novel Merry Riana Mimpi Sejuta Dolar karya Alberthiene Endah.

Seseorang setiap melakukan sesuatu perlu adanya dengan proses. Orang yang mempunyai dengan adanya prinsip teguh pendirian yang kuat melakukan sesuatu akan berhasil. Proses menjalankan sesuatu dengan adanya kegigihan dan fokus akan mencapai kesuksesannya. Hal ini dilihat kutipan berikut.

\section{Data (1)}

Proses dalam ketekunan menjalankan pekerjaan demi pekerjaan itu kemudian secara alamiah mengajarkan aku tentang tiga hal dalam perjuangan tekad yang kuat, strategi yang terarah, dan kedekatan pada Tuhan. Tiga hal itu kemudian menurunkan lagi "anak-anak sikap" yag semuanya mengacu pada satu idealisme jika kita bekerja keras dengan cara yang baik, niat yang baik, dan tekad yang baik, kita bisa meraih impian. (MRMSD, 2011:12)

Kutipan di atas menggambarkan perjuangan dari tokoh Merry Riana untuk menjadi anak muda dengan penghasilan lebih dari satu juta dolar pada usia yang menginjak 26 Tahun. Kerja keras yang ia lakukan membawa hasil yang nyata dalam kehidupannya. Ia tidak pernah menyangka bahwa usaha yang pelanpelan dirintisnya mengantarkannya kepada masa depan yang sungguh cermelang. Usaha keras yang dulu ia lakukan terbayar lunas. Dengan berjalannya waktu hati bisa berubahubah bentuknya. Disituasi yang sama tetapi peristiwa yang berbeda. Hal ini dilihat kutipan berikut.

Data (2)

Namun kesulitan hidup yang menerpaku dengan tiba-tiba dan menggiringiku pada perjalanan dahsyat yang terlalu dini kuhirup telah mendidiku dengan sangat luar biasa. Di masa dimana dalam situasi yang wajar 
aku akan lewatkan hari dengan pola simpel yang kuyakini, aku menjalani hari dengan pikiran yang terus berputar.... (MRMSD, 2011:10)

Kutipan di atas menunjukan dari tokoh Merry Rianan mempunyai tekad untuk bisa membantu meringakan beban orang tuanya, karena Merry Riana sadar bahwa orang tua mengkuliahkannya dengan berbekal utang dengan Bank Singapura. Merry Riana selalu giat berjuang degan segala kesusahan hidup yang dialaminya. Keinginannya yang kuat untuk bertahan dengan orang lain di tengah keadaan hidupnya yang serba kekurangan.

\section{Optimis}

Optimis adalah sikap yang mendorong seseorang untuk beusaha, demi mendapatkan pencapai hasil yang maksimal. Sikap optimis membangun semangan sesorang dalam melakukan sesuatu. Ditemukan ada 2 data dalam novel Merry Riana Mimpi Sejuta Dolar karya Alberthiene Endah.

Berkerja keras berusaha mendapatkan tenaga untuk mendapat hasil yang sesuai. Merry Riana mewujudkan harapannya dengan tidak menunda-nunda waktu. Melakukan dengan nyata apa yang dimaksudkan dengan perjuangan. Hal ini dilihat kutipan berikut.

\section{Data (3)}

Aku mulai bekerja sejak liburan tahun kedua kuliahku, dengan karier awal sebagai penyebar brosur di tempat umum. berbgai jenis pekerjaan kulakukan, pegawai toko bunga, pramusiaji hotel, melakukan jual beli saham, hingga aku akhirnya menyasar ranah pekerjaan sebagai penjual produk keuangan... (MRMSD, 2011:11)

Kutipan di atas menunjukan ketekunan dan keuletan serta rasa patang menyerah dari tokoh Merry Riana akhirnya membentuk pribadinya memiliki kemampuan yang tidak tergoyahkan, mempunyai recana tersusun dengan baik dan dekat terhadap Tuhan. Merry Riana akhirnya menemukan kesadaran bahwa dibalik rintangan yang ia jalani ada kebaikan besar yang sedang Tuhan siapkan untuknya. Oleh karena itu, ia tidak pernah merasa putus asa dan menyerah.

Walau ada rasa takut tetapi harus kupaksa dengan kebernian. Sehingga dengan adanya kepaksaan merupakan jalan keluar untuk berpurapura bahwa berkecukupan di negara orang. Merry Riana menghadapi kenyataan benar-benar sendirian . Hal ini dilihat kutipan berikut.

\section{Data (4)}


Hal pertama yang kubangun dalam diriku untuk bisa menghadapi hari dengan semangat adalah menciptakan sebanyak-banyaknya pikiran positif. Kusadari bahwa itu bukan hal yang mudah untukku, gadis berusia 18 tahun yang dalam waktu 24 jam telah diayun pada kehidupan yang berbeda, tinggal dan studi di negeri orang dalam kondisi finasial yang sangat minim. (MRMSD, 2011:61)

Kutipan di atas menggambarkan keberanian dari tokoh Merry Riana untuk menghadapi hari-harinya. Dengan penuh semangat bisa berfikir positif, mampu berhemat untuk menyesuaikan dengan keadaan yang dilalui dan sanggup merasai ketentraman hidup. Sehingga dapat menyusun strategi yang tepat sehingga tepat sasaran.

\section{Penyesalan}

Dalam kehidupan seseorang saling bersosialisasi. Dalam diri seseorang ada sikap yang biasanya disebut dengan penyesalan. Menyesal dengan kesalahan yang telah diperbuat ataupun tidak disengaja dan tidak akan mengulangi kesalahan yang sama. Ditemukan dalam novel Merry Riana Mimpi Sejuta Dolar karya Alberthiene Endah ada 2 data.

Seseorang mempunyai sikap keikhlasan yaitu menerima apapun tanpa mengandalkan imbalan. Hal ini yang dimaksudkan ikhlas bisa menerima yang diberikan oleh sang pencipta. Hal ini dilihat kutipan berikut.

\section{Data (5)}

Betapa nelangsanya jika gambaran akan kehidupanku di masa itu di putar kembali. Tapi kenyataannya, di masa itu aku bisa bertahan karena kekuatan alamiah yang muncul berkat pola pikir yang kubentuk dengan darurat. Ya, kukatakan darurat karena kondisi di depanku tidak akan memberiku waktu banyak untuk beradaptasi.... (MRMSD, 2011:74)

Kutipan di atas menujukan sikap ikhlas pada tokoh Merry Riana. diwaktu Merry Riana tertipu dengan bisninsnya. Akan tetapi dalam kondisi yang sangat darurat Merry Riana mampu bertahan dalam keadaan apapun. Merry Riana Tidak mau berlarut-larut dalam kesedihan. Seiring berjalannya waktu Merry Riana berusaha mampu dari keadaanya. Sesuatu yang dilakukan denga ikhlas mampu menguasai kerja sama yang baik.

Beberapa hari Merry Riana berdiam. Kiranya sangat sulit untuk mengusir bayangan sudah terbentuk indah. Tapi kenyataanya berbeda 
dengan realitanya. Hal ini dilihat kutipan berikut.

\section{Data (6)}

Jelas ada perasaan sakit di batinku. Saat itu aku masih snagat muda dan kedewasaanku belum terbentuk solid, sehingga kekecewaan yang dalam sempat membuatku nyaris kehilangan harapan. Aku teringat bagaimana besarnya optimisme yang terbentuk.... (MRMSD, 2011:185)

Kutipan di atas menggambarkan kecewanya dari tokoh Merry Riana yang kemungkinan akan kehilangan harapannya. Harapan yang penuh optimis ingin sukses berbisnis saat usia muda. Merry Riana selalu bersemangat sebaik mungkin agar berhasil mengembangkan jejaring dalam usahanya.

\section{b. Hubungan Manusia dengan Manusia dalam Lingkungan Sosial}

Makhluk sosial memiliki ketergantungan di lingkungannya. Hubungan manusia dengan lingkungannya ialah hubungan yang saling menguntungkan satu sama yang lain. Dalam novel Merry Riana Mimpi Sejuta Dolar karya Alberthiene Endah terdapat nilai moral hubungan manusia dengan manusia lain dalam lingkup sosial. Wujud hubungan manusia dengan manusia dalam lingkup lingkungan sosial meliputi peduli sesama, berterimakasih, menghargai orang lain, dan jujur.

\section{Peduli sesama}

Banyak hal yang seseorang lakukan agar hidupnya bermakana. Seseorang tidak bisa hidup sendirian mereka memliki bantuan satu sama lain sehingga bisa saling menguntungkan. Dalam novel Merry Riana Mimpi Sejuta Dolar karya Alberthiene Endah ditemukan ada 2 data.

Pasangan ialah teman yang melakukan suatu perjuangan untuk mencapai tujuan tertentu. Didikan saling percaya dan memberikan tujuan yang tepat sesuai yang diinginkan. Hal ini dilihat kutipan berikut.

\section{Data (7)}

...Sejak berpacaran dengan alva, dan memiliki niat serius untuk masuk ke jenjang pernikahan, aku tahu permulaan apa yang harus kami buat. Yang harus kami bina adalah melatih diri kami untuk menjadi "pembentuk" sukses satu sama lain. Dan pada akhirnya menjadi sukses bersama.... (MRMSD, 2011:204)

Kutipan di atas menunjukan Merry Riana dan Alva saling peduli untuk menjadi sukses bersama. Dengan berkerja sama yang erat dapat memperoleh maksud yang jelas. 
Dengan bantuan orang lain dapat memperoleh semangat saat melakukan sesuatu. Dengan bekerja sama mempererat hubungan. Merry Riana mempunya tekad dalam bekerja untuk mendapatkan uang. Hal ini dilihat kutipan berikut.

\section{Data (8)}

Aku dan Alva bertekad bekerja sama. Itu tidak menjadi masalah bagi kantor. Yang penting perhitungannya baku, aku akan mendapatkan komisi dari hasil penjualanku.... (MRMSD, 2011:224).

Kutipan di atas menunjukan dari tokoh Merry Riana dan Alva saling mempunyai tekad untuk bekerja sama dalam pekerjaannya untuk meraih kesuksesan. Merry Riana dan Alva setuju untuk membagi tugas dalam memulai pekerjaannya. Merry Riana bekerja dengan sungguh-sungguh menjalankan tugasnya dalam bekerja. Dan Alva bertugas menjadi pengatur strategi dalam menjalan pekerjaana untuk mendapatkan klien atau nasabah.

\section{Berterima kasih}

Berterima kasih bukan hanya untuk meminta tolong kepada orang lain atau saat seseorang diberikan hadiah. Berterima kasih ialah ucapan dengan penuh rasa syukur dengan tulus apa yang seseorang dapatkan dari orang lain. Dalam novel Merry Riana
Mimpi sejuta Dolar karya Alberthiene Endah ditemukan ada 1 data.

Merry Riana sangat sulit untuk bisa cepat beradaptasi dengan karunia itu. Alva yang membantuku untuk berkerja sama dalam melalukan pekerjaan. Hal ini dilihat kutipan berikut.

\section{Data (9)}

Tak pelak lagi, kepercayaan diriku berkembang saat itu. Aku merasa telah melihat "daya" yang luar biasa di diriku, dan aku bangga karenannya. Kemampuanku diakui orang. Alva menjadi sosok yang sangat bahagia. Dia terus menggenggam tanganku. "kamu sangat membuat aku bangga, Ria” katanya. Aku menatap Alva dengan pandangan penuh terimakasih.... (MRMSD, 2011:274)

Kutipan di atas menunjukan dari tokoh Merry Riana berterima kasih pada Alva. Merry Riana merasakan berkembangnya daya yang luar biasa. Alva ialah sosok lelaki yang kuat serta memiliki pengaruh besar dalam kesuksesannya. Betapa luar biasanya kebesaran hati Alva. Dia memberikan aku beserta waktunya.

\section{Menghargai orang lain}

Seseorang wajib memiliki watak saling menghargai sesama manusia. Saling menghargai ialah bisa menerima tanggapan orang lain dalam 
suatu permasalahan. Dalam novel Merry Riana Mimpi Sejuta Dolar karya Alberthiene Endah ditemukan ada 2 data.

Merry Riana tiada henti memupuk kemampuannya untuk bisa mendapatkan uang dan Alva tiada henti memberi pikirannya untuk bergerak berkerja keras demi mendapatkan uang. Di masa itulah melekatkan kita untuk bekerja sama sehingga bisa menghargai. Hal ini dilihat kutipan berikut.

\section{Data (10)}

Pemikiran kami bahwa sebaiknya kami tidak mengerjakan satu hal yang sama, ternyata ada benarnya. Dengan menbagi tugas seperti ini, aku bisa bekerja dengan kelebihanku, dan Alva bekerja dengan kelebihannya. Hasilnya sinergi yang saling melengkapi. (MRMSD, 2011:241)

$$
\text { Kutipan di atas }
$$

menggambarkan sikap menghargai dari tokoh Merry Riana ketika membagi tugasnya dengan Alva. Dengan saling menerima kelebihan satu sama lain mendapatkan hasil yang sangat mendukung. Sikap Menghargai merupakan suatu sikap yang saling menghormati satu sama lain.

Merry Riana dan Alva menerapkan perekrutan anak buah yang khas. Ujiannya meminta mereka berbicara untuk kegiatan dan melakukan edukasi. Dari kegiatan itu bisa terlihat pribadi yang bisa dipercaya. Hal ini dilihat kutipan berikut.

\section{Data (11)}

Ujian di camp itu sangat dramatis, Aku dan Alva menerapkan cara eliminasi setiap beberapa jam sekali. Kami akan mengumpulkan mereka dan mengatakan bahwa si A atau si B tidak lulus dan dipersilakan untuk kembali kerumah. Momen menegangkan itu benar-benar dramatis. Banyak yang menangis, bahkan ada sorang perempuan dari Beijing yang tidak mau bergerak dari tempat ia duduk. Ia memohon untuk diberi ujian sekali lagi.... (MRMSD, 2011:287)

Kutipan di atas menunjukan sikap menghargai dari tokoh Merry Riana dan Alva memberikan kesempatan kepada seorang perempuan dari Beijing yang memohon untuk di berikan ujian sekali lagi. Memberikan waktu seseorang untuk memutuskan sebuah tindakan terhadap orang lain. Tetapi dia tidak menunjukan kegigihan menjadi seorang sales pada akhirnya tidak lolos. Betapa orang lain pada umumnya menginginkan diberikan semangat. 


\section{Jujur}

Seseorag dikatakan bersikap jujur artinya tidak bohong dalam perkataan dan tingkah lakunya. Jujur ialah tingkah laku seseorang yang dapat atau bisa dipercayai perkataannya oleh orang lain. Dalam novel Merry Riana Mimpi Sejuta Dolar karya Alberthiene Endah ditemukan ada 2 data. Pikiran kritis tetep berjalan menuju ketika menuju waktu kelulusan menjadi sarjana di NTU. Merry Riana meyakinkan hubungannya dengan Alva. Hal ini dilihat kutipan berikut.

\section{Data (12)}

Pikran-pikiran kritis itu mewarnai bennakku di masa perayaan terhadap kelulusan menjadi sarjana. Dan kebahagiaanku bukan hanya itu. Hubungan dengan Alva telah sampai ke jenjang yang meyakinkan. Bukan hanya meyakinkan diriku, tapi juga keluarga. Aku merasakan pengalaman batin yang sangat indah bersama Alva.... (MRMSD, 2011:203)

$$
\text { Kutipan di atas }
$$

menggambarkan keterbukaan dari tokoh Merry Riana karena merasakan pengalamanan batin yang sangat indah bersama suaminya. Keterbukanaan merupakan salah satu bentuk kejujuran. Dengan adanya cinta dapat memberikan semangat dan keadaan dapat memberikan kemampuan yang positif. Alva ialah laki-laki yang sesuai untuk Merry Riana.

Memasuki ruang seminar dengan perasaan yang bergejolak. Kesempatan berbicara yang pertama sejak terpilih sebagai President berprestasi di bisnis konsultan keuangan. Hal ini dilihat kutipan berikut.

\section{Data (13)}

Aku melangkah ke podium. Mataku nyaris basah kalau saja aku tidak matimatian menahannya. Pidatoku malam itu terbatas. Dengan suara tersendat, aku menceritakan bagaimana aku memulai pekerjaanku. Kukisahkan secara jujur bagaimana aku memulai pekerjaanku.... (MRMSD, 2011:324)

Kutipan di atas menggambarkan keterbukaan dari tokoh Merry Riana saat menceritakan bagaimana memulai pekerjaannya. Pada detik itu teringat ketahun sebelumnya, Merry Riana merasa khawatir saat ke Singapura dan menggambarkan apa yang terjadi. Dengan cinta orang tua dapat menimbulkan semangat dalam meraih kesuksesan.

\section{c. Hubungan Manusia dengan Tuhan}

Seseorang mempunyai kewajiban terhadap Tuhan-Nya. Tugas melaksanakan aturan serta 
meninggalkan sesuatu yang dilarang. Novel Merry Riana Mimpi Sejuta Dolar karya Alberthiene Endah yang menganalisis nilai moral, antara lain hubungan manusia dengan Tuhan, yang berkaitan dengan agama. Karya sastra yang baik harus dapat mencerminkan nilai moral dalam agama. Karya sastra merupakan arti kehidupan yang nyata. Karya sastra yang mencerminkan nilai agama dapat mempengaruhi pembaca kearah kehidupan yang lebih teratur. Setiap nilai moral agama selalu mengajak kepada manusia agar selalu berbuat baik seperti saling berhubungan dengan Tuhan dengan manusia, hewan, ataupun kepada alam ciptaan-Nya. Berikut data yang menunjukan nilai moral hubungan manusia dengan Tuhan. Wujud nilai moral dalam hubungan manusia dengan Tuhan meliputi kepercayaan terhadap Tuhan, Bersyukur kepada Tuhan, Memanjatkan Doa.

\section{Kepercayaan terhadap Tuhan}

Seseorang percaya adanya Tuhan. Kepercayaan terhadap Tuhan segala sesuatu dalam hal keyakinan yang mempercayai adanya Tuhan. Dalam novel Merry Riana Mimpi Sejuta Dolar karya Alberthien Endah ditemuka 1 data.

Percaya adanya Tuhan ialah wujud iman seseorang. Percaya bearti bahwa seseorang yakin atau mempercayai bahwa Tuhan itu ada. Hal ini dilihat kutipan berikut.

\section{Data (14)}

Selain partner yang sevisi dan memiliki energi yang positif, yang terpenting adalah partner tertinggi, yakni Tuhan. Aku tidak pernah lupa dialogku dengan Tuhan. Terlebih di masa-masa yang berat selama di NTU. Beribadah bagiku bukan semata menjalankan ajaran agama, tapi merupakan cara untuk menyerahkan hidupku dipimpin oleh-Nya.... (MRMSD, 2011:176)

$$
\text { Kutipan di atas }
$$
menggambarkan yakinnya dan percaya dari tokoh Merry Riana kepada Tuhan. Marry Riana percaya saat dalam keadaan yang sulit Tuhan ada memberikan bantuan. Kepercayaan pada Tuhan dapat memperoleh keadaan yang tenang dan tentram.

\section{Bersyukur kepada Tuhan}

Rasa bersyukurnya seseorang diperlihatkan melalui tindakan dan perkataan yang diucapakannya. Bersyukur ialah mengucapkan syukur atas pemberian yang Tuhan berikan. Ditemukan ada 2 data dalam novel Merry Riana Mimpi Sejuta Dolar karya Alberthiene Endah.

Tidak ada akan berkeluh kesah semua teman-teman seperjalanan 
menuju Singapura. Pada diri Merry Riana bersyukur kepada Tuhan karena dikelilingi oleh orang-orang yang dikenalnya ketika akan brangkat ke Singapura. Hal ini dilihat kutipan berikut.

\section{Data ( 15)}

Ini merupakan berkat Tuhan yang kusyukuri, bahwa aku berangkat bersama dengan rombongan siswi yang sebagaian besar telah aku kenal. Rupanya daya tarik NTU memang cukup menyengat lulusan Ursula. Atau ya, faktor kerusuhan yang membuat banyak orang yang mengubah haluan tempat kuliah menjadi tujuan favorit karena tersedia progam beasiswa dan pinjaman biaya hidup serta pendidikan dan pemerintahnya. (MRMSD, 2011:44)

Kutipan di atas menggambarkan dari tokoh Merry Riana bersyukur pada Tuhan karena diberikan kekuatan ketika akan kuliah di NTU. Merry Riana untuk berangkat ke NTU dengan teman-temannya yang kebanyakan warga keturunan Tionghoa di jakarta ke Singapura. Kekuatan itu tersimpan dan menunjukannya dengan secara natural.

Merry Riana mencari kegiatan menenangkan. Melalui proses pedalaman agama yang tentram dikampusnya. Hal ini dilihat kutipan berikut.

\section{Data (16)}

Setelah mencari informasi yang cukup dari kampus, ku tahu ada pendalaman Kitab Suci pada hari tertentu. Segera aku memastikan untuk ikut. Inilah sebuah keputusan yang kemudian membawaku pada perkenalan dengan seseorang yang sangat penting. Seseorang yang di kemudian hari kelak menjadi suamiku Alva Tjenderasa. (MRMSD, 2011:80)

Kutipan di atas menunjukan rasa bersyukurnya dari tokoh Merry Riana kepada Tuhan karena telah mempertemukan aku dengan sesorang yang kemudian menjadi suaminya yaitu Alva Tjenderasa. Berkenalan dengan singkat di kampus pada pelajaran pendalaman kitab suci. Bersyukur ialah mengucap syukur kepada Tuhan karena diberikan karunia yang berlimpah oleh Tuhan.

\section{Memanjatkan doa}

Seseoramg memanjatkan doa untuk meminta segala sesuatu. Doa ialah permohonan seseorang kepada Tuhanya. Dalam novel Merry Riana Mimpi Sejuta Dolar karya Alberthiene Endah ditemukan ada 1 data.

Memanjatkan doa sebagai keaktifan seseorang yang dilakukan untuk meminta.seseorang berdoa untuk 
meminta atau memohon perlindungan kepada Tuhan supaya diberikan keselamatan. Hal ini dilihat pada kutipan berikut.

\section{Data (17)}

Aku berdoa dengan khusyu. Memohon pada Tuhan supaya aku dikuatkan, supaya semangatku tetap teguh dan tidak ada optimisme yang runtuh. Aku ingat pada suatu sore aku tak bisa menahan air mataku saat melakukan ibadah rosario dan berdoa novena. (MRMSD, 2011:186)

Kutipan tersebut pada diri tokoh Merry Riana berdoa dengan khusyu kepada Tuhan. Merry Riana memohon kepada Tuhan agar diberikan energi yang kuat untuk perjuangannya. Meminta sesuatu dapat memperoleh kebaikan waktu berdoa.

\section{B. Implikasi Nilai-Nilai Moral pada Pembelajaran Bahasa Indonesia di SMA}

Hasil penelitian ini berkaitan dengan pembelajaran bahasa Indonesia di SMA. Salah satu pembelajaran bahasa Indonesia yang berkaitan dengan sastra. Tujuan pembelajaran sastra di sekolah untuk supaya peserta didik mempunyai keterampilan, pengetahuan dan kepribadian yang selaras dengan norma ada di masyarakat.
Berdasarkan

Standar

Kompetensi (SK), Kompetensi Dasar (KD) 3.9 menganalisis isi dan kebahasaan untuk menentukan isi novel berdasarkan unsur intrisik dan ekstrinsik dalam novel, maka penelitian tentang nilai moral dalam novel dapat dijadikan sebagai materi pembelajaran Bahasa Indonesia. Peneliti cuma fokus terhadap unsur ekstrinsik ialah tentang nilai moral. Dengan adanya nilai moral akan menambah pengetahuan yang sangat positif. Novel Merry Riana Mimpi Sejuta Dolar karya Alberthiene Endah di ajarkan di SMA, karena di dalam novel Merry Riana Mimpi Sejuta Dolar ini isinya yang menarik serta memberi arti kebaikan seperti rajin dan teliti, sabar, setia, pantang menyerah, berpikir positif, serta sangat positif di baca peserta didik.

\section{KESIMPULAN}

Pemerolehan wujud nilai moral dalam novel Merry Riana Mimpi Sejuta Dolar terdapat tiga wujud. Wujud yang terdapat nilai moral ialah nilai moral dalam hubungan manusia dengan diri sendiri $52,5 \%$, nilai moral dalam hubungan manusia dengan manusia lain dalam lingkup sosial 25\%, dan hubungan manusia dengan Tuhannya 22,5\%. Implikasi hasil penelitian dalam novel Merry Riana Mimpi Sejuta Dolar karya Alberthine Endah memperoleh proses 
belajar Bahasa Indonesia di SMA kelas XII materi menikmati novel dengan Kompetensi Dasar 3.9 menganalisis isi dan kebahasaan dalam novel dengan indikator menganalisis isi. Novel ini layak diajarkan untuk peserta didik karena isi yang terkandung dalam novel sungguh positif. Sifat positif itu yang layak dijadikan contoh bagi peserta didik (pembaca).

\section{SARAN}

Penelitian nilai moral dalam novel Merry Riana Mimpi Sejuta Dolar karya Alberthiene Endah memakai metode deskriptif kualitatif agar mudah di pahami. Diharapkan bisa membuka wawasan dan menggungah semangat dalam belajar serta meraih cita-cita setinggi mungkin. Semoga penelitian ini bermanfaat bagi semua yang membaca, maupun bisa menjadi referensi untuk penelitian selanjutnya.

\section{DAFTAR PUSTAKA}

Endah, A. 2012. Merry Riana Mimpi Sejuta Dolar. Jakarta : PT. Gramedi Pustaka Utama.

Moleong, Lexy J. 2006. Metode Penelitian Kualitatif. Bandung : PT. Remaja.

Muslich, M. 2015. Pendidikan Karakter: Menjawab tantangan krisis multidimensial. Jakarta : Bumi Aksara.

Nugiantoro, Burhan. 2013. Teori Pengkajian Fiksi. Yogyakarta : Gajah Mada Iniversiti Pres.
Salam, B. 2012. Etika Individual : Pola dasar filsafat moral. Jakarta : PT. Rinaka Cipta.

Siagian, P. 2012. Teori Motivasi dan Aplikasinya. Jakarta : PT. Rineka Cipta.

Sugiyono. 2011. Metode Penelitian Kualitatif, Kualitatif, dan $R \& D$. Bandung: Alfabet.

Wulansih. 2017. Aspek Motivasi pada Novel Merry Riana Mimpi Sejuta Dolar Karya Alberthiene Endah: Tinjauan Psikologi Sastra dan Implementasinya sebagai Ban Ajar Sastra di SMA. Surakarta : Universitas Muhammdiyah Surakarta.

Wicaksono. 2017. Hakikat Novel. Malang : UMM Press. 